\title{
New Insights into How Trafficking Regulates T Cell Receptor Signaling
}

\author{
Jieqiong Lou ${ }^{1,2}$, Jérémie Rossy ${ }^{1,2}$, Qiji Deng ${ }^{1,2}$, Sophie V. Pageon ${ }^{1,2}$ and \\ Katharina Gaus ${ }^{1,2 *}$ \\ ${ }^{1}$ EMBL Australia Node in Single Molecule Science, School of Medical Sciences, University of New South Wales, Sydney, \\ NSW, Australia, ${ }^{2}$ ARC Centre of Excellence in Advanced Molecular Imaging, University of New South Wales, Sydney, NSW, \\ Australia
}

\section{OPEN ACCESS}

Edited by:

Marek Cebecauer,

J. Heyrovsky Institute of Physical

Chemistry, Czech Republic

Reviewed by:

Wolfgang W. Schamel,

University of Freiburg, Germany

Andres Alcover

Institute Pasteur, France

*Correspondence:

Katharina Gaus

k.gaus@unsw.edu.au

Specialty section:

This article was submitted to Membrane Physiology and Membrane

Biophysics,

a section of the journal

Frontiers in Cell and Developmental

Biology

Received: 22 April 2016

Accepted: 11 July 2016

Published: 26 July 2016

Citation:

Lou J, Rossy J, Deng Q, Pageon SV and Gaus K (2016) New Insights into

How Trafficking Regulates T Cell

Receptor Signaling

Front. Cell Dev. Biol. 4:77.

doi: 10.3389/fcell.2016.00077
There is emerging evidence that exocytosis plays an important role in regulating $T$ cell receptor (TCR) signaling. The trafficking molecules involved in lytic granule (LG) secretion in cytotoxic T lymphocytes (CTL) have been well-studied due to the immune disorder known as familial hemophagocytic lymphohistiocytosis (FHLH). However, the knowledge of trafficking machineries regulating the exocytosis of receptors and signaling molecules remains quite limited. In this review, we summarize the reported trafficking molecules involved in the transport of the TCR and downstream signaling molecules to the cell surface. By combining this information with the known knowledge of LG exocytosis and general exocytic trafficking machinery, we attempt to draw a more complete picture of how the TCR signaling network and exocytic trafficking matrix are interconnected to facilitate $T$ cell activation. This also highlights how membrane compartmentalization facilitates the spatiotemporal organization of cellular responses that are essential for immune functions.

Keywords: TCR signaling, exocytic trafficking, LAT, Rabs, SNAREs

\section{INTRODUCTION}

The key signaling molecules involved in the T Cell Receptor (TCR) signaling network have been well-characterized. T cell signaling is initiated upon TCR engagement by major histocompatibility complex (MHC) molecules bound to peptide antigens (pMHC). Upon TCR engagement, the TCRassociated $\mathrm{CD} 3$ dimers are phosphorylated by the kinase Lck on intracellular immunoreceptor tyrosine-based activation motif (ITAM) consensus sites, leading to the recruitment and activation of downstream signaling molecules, such as the adaptor protein Linker for Activated T cells (LAT). Subsequent activation responses including the secretion of lytic granules (LG) target infected or cancer cells for lysis. The formation of a structured interface between a $\mathrm{T}$ cell and an antigenpresenting cell (APC), termed the immunological synapse, is critical for the efficient delivery of effector molecules to the APC and intracellular signals in the T cell. The architecture of the immunological synapse was first described in 1998 as a "bull's eye pattern," consisting of the central supramolecular activation cluster (cSMAC), where signaling molecules such as the TCR accumulated, surrounded by a ring of adhesion molecules known as the peripheral SMAC (pSMAC), with other molecules such as CD45 being excluded and localized in the distal SMAC (dSMAC, Figure 1; Monks et al., 1998; Grakoui et al., 1999; Freiberg et al., 2002).

Fluorescence microscopy has aided our understanding of the mechanisms underlying the coalescence and segregation of receptors and signaling molecules in the plasma membrane during synapse formation. Many studies focused on how the two-dimensional organization of proteins 


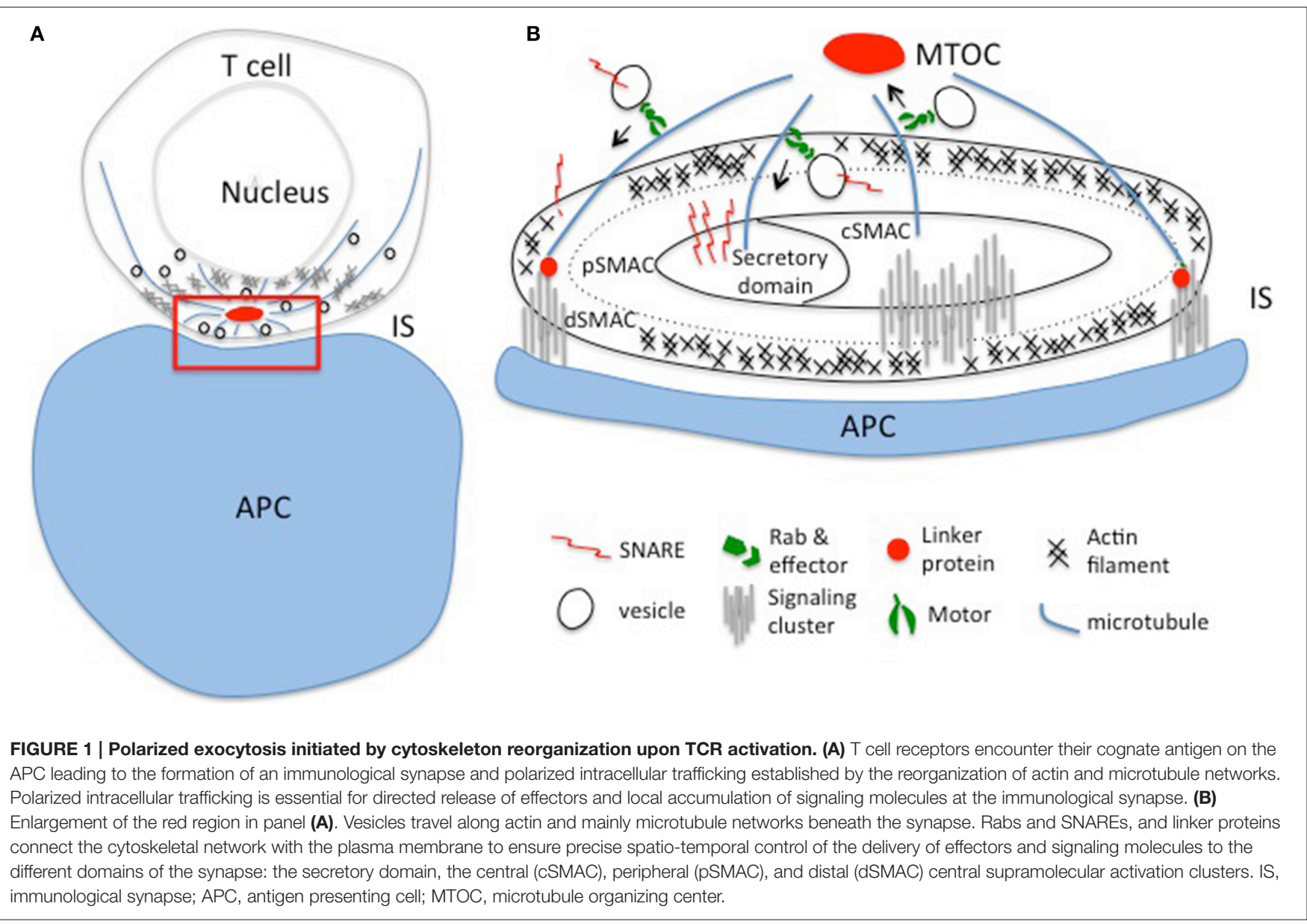

within the synapse contributes to $\mathrm{T}$ cell activation. However, as three-dimensional objects, cells can utilize an additional layer of regulatory mechanisms to control TCR signaling outcomes. Emerging evidence suggests that intracellular vesicular trafficking plays an important role in orchestrating TCR signaling. Engaged TCRs are internalized and targeted for degradation, but can also remain phosphorylated and signaling-competent (Luton et al., 1997; Coombs et al., 2002; Yudushkin and Vale, 2010; Benzing et al., 2013). Continuous delivery of the TCR into the immunological synapse is essential for sustained signaling and T cell activation (Grakoui et al., 1999; Lee et al., 2003; Soares et al., 2013b; Choudhuri et al., 2014; Martin-Cofreces et al., 2014). For example, although Lck activity is enhanced by TCR ligation (Stirnweiss et al., 2013), it is thought that the spatial organization and subcellular redistribution of Lck, in conjunction with antigen-binding induced conformational changes of the TCRCD3 complex (Martinez-Martin et al., 2009; Swamy et al., 2016), control the extent of TCR-CD3 phosphorylation (Ehrlich et al., 2002; Thoulouze et al., 2006; Anton et al., 2008; Nika et al., 2010; Rossy et al., 2013). In the case of the adaptor protein LAT, the docking of sub-synaptic vesicles was observed in response to the initial wave of TCR signaling to sustain TCR signaling (Bonello et al., 2004; Billadeau, 2010; Purbhoo et al., 2010; Williamson et al., 2011; Larghi et al., 2013). In addition to the classical process of vesicles forming inside the cell, docking, and fusing at the immunological synapse, TCR-enriched microvesicles can also form and be released from the center of the IS to transmit signals to the APC (Choudhuri et al., 2014).

In $\mathrm{T}$ cells, there is a continuous flow of proteins and membranes along the endocytic and exocytic pathways. When a T cell encounters an APC, ligation of the TCR with cognate pMHC molecules leads to rapid cytoskeletal reorganization/polarization, which ensures the initiation of receptor and signaling protein endocytosis, and polarized secretion of LG and other vesicles (Dustin and Cooper, 2000; Angus and Griffiths, 2013). The internalization of the TCR-CD3 complex and downstream signaling proteins including LAT and SLP76 (SH2 domain containing leukocyte protein of $76 \mathrm{kDa}$ ) is relatively well-studied. Upon TCR activation, both engaged and bystander TCR can be internalized by clathrin independent, and/or dependent endocytosis (Monjas et al., 2004). Internalized engaged TCR-CD3 complexes are mainly degraded, while bystander TCR-CD3 complexes are predominately recycled back to the immunological synapse (Liu et al., 2000; Monjas et al., 2004; von Essen et al., 2004). SLP76 and LAT are first recruited to TCR and ZAP70 clusters in the plasma membrane and then segregate from these clusters during the transport of engaged TCR toward the central region of the immunological synapse 
within the membrane. This initiates LAT and SLP76 endocytosis (Barr et al., 2006). Internalized LAT were found to co-localize with transferrin positive vesicles, indicating a clathrin-mediated endocytic trafficking route, as well as cholera toxin B positive vesicles that do not co-localize with transferrin-positive vesicles in T cells and distinct SLP76-positive vesicles (Balagopalan et al., 2009). The E3 ubiquitin ligase $\mathrm{Cbl}$ and Cbl-b are known to play a key role in both TCR and LAT internalization (Naramura et al., 2002; Balagopalan et al., 2007). Noteworthy, no detectable LAT degradation seems to occur in response to TCR activation, indicating LAT is mainly recycled instead of being degraded after internalization, although LAT was ubiquitinated in response to TCR signaling (Balagopalan et al., 2007).

Vesicles containing cargo such as signaling molecules or effector molecules are transported along the microtubules or actin filament networks by molecular motors and delivered to the immunological synapse. The precise sorting and delivery of cargo are dependent on a subfamily of Ras GTPases, called Rab proteins (Fukuda, 2008; Wandinger-Ness and Zerial, 2014), and on membrane docking and fusion machinery proteins, known as soluble N-ethylmaleimide-sensitive-factor accessory-protein receptors (SNAREs; Das et al., 2004; Jahn and Scheller, 2006; Figure 1). Endosomal sorting complexes required for transport (ESCRT) components mediate the release into the extracellular space of vesicles that form at the immunological synapse (Choudhuri et al., 2014). In this review, we will summarize the known Rab and SNARE proteins involved in both the delivery of signaling molecules and the secretion of effectors at the immunological synapse in response to TCR activation. We will also summarize the known protein-protein interactions that may facilitate efficient and precise delivery of signaling moleculecontaining vesicles in the activated TCR signaling network, using LAT-containing vesicles as an example.

\section{EXOCYTOSIS MACHINERY OF EFFECTOR AND SIGNALING MOLECULES}

The TCR and downstream signaling proteins undergo constant internalization and exocytosis in resting $\mathrm{T}$ cells (Geisler, 2004). Upon TCR activation, polarized exocytosis is initiated by cytoskeletal rearrangements, which may be sufficient for receptors and signaling molecules to locally accumulate in the immunological synapse. So far, little is known about the molecular machinery involved in exocytosis of TCR and TCR signaling proteins, neither in resting nor in activated $\mathrm{T}$ cells. The monomeric $\mathrm{G}$ protein Rabs are the coordinators of intracellular membrane trafficking of TCR and downstream signaling proteins. Soares and colleagues have evaluated he role of 17 Rabs known to be involved in exocytic processes and examined TCR, Lck, and LAT exocytosis during TCR activation. They demonstrated that TCR $\zeta$ can be delivered to the immunological synapse from fast recycling Rab4b compartments. A newly synthetized pool of TCR is also brought to the immunological synapse via Rab3d and Rab8b-positive compartments (Soares et al., 2013a). In addition, the TCR has been reported to colocalize with Rab35 and transferrin-positive compartments. It has been further shown that a Rab35-dominant negative mutation impairs TCR enrichment at the immunological synapse (Das et al., 2004; Patino-Lopez et al., 2008). Lck-containing vesicular compartments co-localized with the recycling endosome marker Rab11b (Soares et al., 2013a). Further, LAT vesicles co-localized with late endosome marker Rab7, newly synthesized protein pool Rab8 positive compartments, as well as Rab27a and Rab37, two Rab molecules known to regulate LG and cytokine secretion, respectively (Hong, 2005; Fischer et al., 2007; Purbhoo et al., 2010; Fukuda, 2013; Soares et al., 2013a; Figure 2). Hence, according to these studies, there is very little overlap between the identities of vesicles containing the TCR, Lck, and LAT, which suggest that distinct trafficking mechanisms exist for different signaling molecules. Hence, the intracellular reservoir of TCR, Lck, and LAT destined for transport to the plasma membrane and/or exocytosis are clearly distinct from each other, and range from slow and fast recycling compartments, to Golgi, and late endosome/lysosome (Figure 2). The contribution of this complex organization to $\mathrm{T}$ cell signaling and activation remains to be fully understood.

In general, GTP-bound active Rab proteins regulate many steps of intracellular membrane trafficking by recruiting different effectors to restricted membrane domains (Grosshans et al., 2006). Rab effectors are very diverse and can be divided into three groups according to the vesicle trafficking steps they are involved in, such as vesicle formation, trafficking along cytoskeletal networks, and vesicle fusion. Within the LG secretion pathway, the role of Rab27a and its effectors has been identified in relation to familial hemophagocytic lymphohistiocytosis (FHLH) and Griscelli syndrome type2 (GS; Fukuda, 2008, 2013; Krzewski and Cullinane, 2013). Granule exocytosis by cytotoxic T lymphocytes (CTLs) is defective in these patients, and this was found to be due to dysfunctional Rab27a (Menasche et al., 2000; Haddad et al., 2001). Rab27a effectors are synaptotagmin-like proteins (Slp) and typically contain a Slp homology domain (SHD, Rab27a-binding domain) and two C2 domains (for binding to phospholipids and potentially calcium). Slp3-a forms a complex with Rab27a and the motor protein kinesin-1 and was demonstrated to mediate the terminal transport of LG to the immune synapse (Kurowska et al., 2012). There is evidence that Slp2-a is also involved in docking of LG in CTLs by binding to Rab27a and the plasma membrane (Menasche et al., 2008). Mutations of another Rab27a effector (Holt et al., 2008), Munc13-4, caused immunodeficiency in patients with type 3 FHLH. Munc13-4 plays a role in LG maturation and also drives the SNARE assembly process and is critical for the priming/fusion step of LG exocytosis (Feldmann et al., 2003). In addition, Munc13-4 has been also demonstrated to mediate fusion of Rab11-positive recycling vesicles with Rab27-positive late vesicles, constituting a pool of vesicles destined for regulated exocytosis (Menager et al., 2007). Munc18-2 promotes SNARE complex assembly (Hackmann et al., 2013; Spessott et al., 2015) and is not a direct effector but binds to another Rab27a effector, Slp-4a (Fischer et al., 2007; Jenkins and Griffiths, 2010; Hackmann et al., 2013; Krzewski and Cullinane, 2013).

Until now, limited information has been obtained regarding the role of Rab effectors in the regulation of exocytosis of 


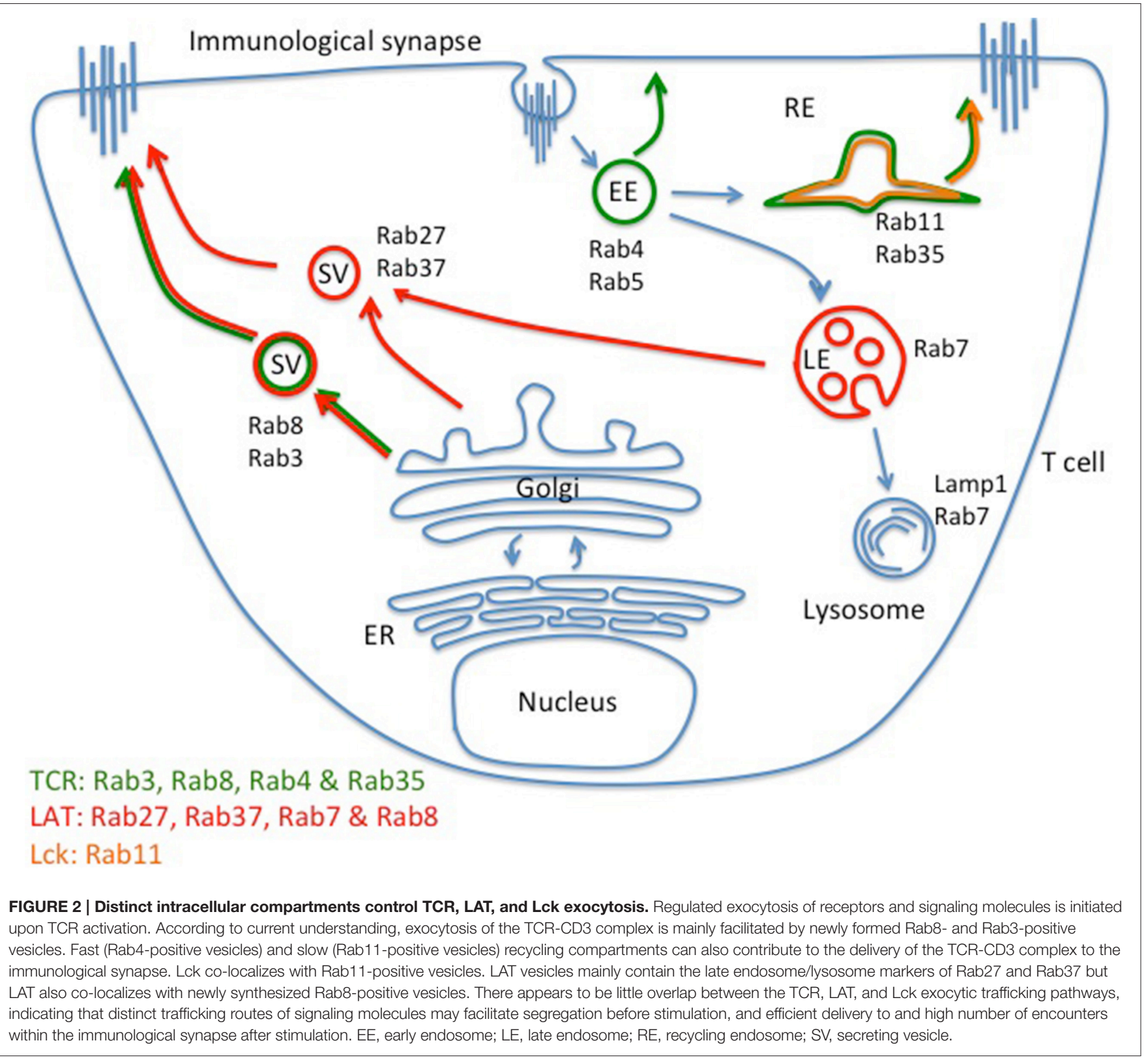

TCR and signaling molecules. Table 1 summarizes the known effectors that are expressed in $\mathrm{T}$ cells for Rabs involved in exocytosis of TCR and signaling molecules (Grosshans et al., 2006; Fukuda, 2013; Wandinger-Ness and Zerial, 2014). Through Rab effectors, the Rab network is connected to the SNARE system, linking the transportation of exocytic vesicles in the cytosol to their docking and fusion with the plasma membrane. Prior to membrane fusion, SNAREs on opposing membranes are able to form four-helix bundles that lead to a tight connection of vesicular and target membranes. SNARE complexes can be divided into two groups, vesicle SNAREs (vSNAREs), and target membrane SNAREs (tSNAREs). SNAREs can also be divided into either Q- (Qa, Qb, Qc, or Qbc, mainly tSNAREs) or R-SNAREs (mainly vSNAREs) based on their structure. In general, the four helix-bundle of a functional SNARE complex must consist of one Qa-SNARE, one Qb-SNARE, one Qc-SNARE, and one RSNARE. In some cases, the two helices of the Qb- and the QcSNARE can be provided by one protein (Jahn and Scheller, 2006). In addition to the core SNARE complex, the calcium sensors synaptotagmins, and synaptotagmin-like proteins facilitate the assembly of the SNARE complex and trigger the final membrane fusion step.

Pattu and colleagues have examined the expression of 28 SNAREs and their co-localization with LGs and TCR-CD3 complex in synapses in primary human CD8+ $\mathrm{T}$ cells. They found that Stx16 Vtib and Stx8 had the highest co-localization with LGs while TCR-CD3 co-localized with Stx3, Stx4, Stx7, Stx13, Vtib, Stx6, Stx8, VAMP3, and VAMP4 (Pattu et al., 2012). 
TABLE 1 | Effectors for Rabs involved in the exocytosis of TCR and TCR signaling molecules.

\begin{tabular}{|c|c|c|c|c|}
\hline $\begin{array}{l}\text { Signaling } \\
\text { molecule }\end{array}$ & Rabs & Effectors & $\begin{array}{l}\text { Effector expression } \\
\text { in } \mathrm{T} \text { cell }\end{array}$ & Proposed functions \\
\hline \multirow[t]{21}{*}{ TCR } & Rab3d & $\begin{array}{l}\text { Regulating synaptic membrane exocytosis } \\
1 / 2(R I M S 1 / 2)\end{array}$ & Low/medium & $\begin{array}{l}\text { Regulates synaptic vesicle exocytosis, } \\
\text { regulates voltage-gated calcium channels, } \\
\text { scaffolding protein (Millar et al., 2002; Gandini } \\
\text { et al., 2011) }\end{array}$ \\
\hline & & $\begin{array}{l}\text { Rabphilin 3A like (without C2 domain; } \\
\text { RPH3AL) }\end{array}$ & Low & $\begin{array}{l}\text { A direct regulatory role in calcium } \\
\text { ion-dependent exocytosis (Li et al., 1994; Millar } \\
\text { et al., 2002; Grosshans et al., 2006) }\end{array}$ \\
\hline & Rab4b & $\begin{array}{l}\text { Rabaptin, Rab GTPase-binding effector } \\
\text { protein } 1 \text { (RabEP1) }\end{array}$ & High & $\begin{array}{l}\text { Acts as a linker between adaptin and Rab4 and } \\
\text { Rab5, involved in endocytic membrane fusion } \\
\text { (Vitale et al., 1998) }\end{array}$ \\
\hline & & $\begin{array}{l}\text { RUN and FYVE domain containing } 1 \\
\text { (RUFY1) }\end{array}$ & Medium & $\begin{array}{l}\text { Binds to phospholipid vesicles and participates } \\
\text { in early endosomal trafficking (Cormont et al., } \\
\text { 2001; Fouraux et al., 2004) }\end{array}$ \\
\hline & & $\begin{array}{l}\text { RAB11 family-interacting protein } 1 \\
\text { (RAB11FIP1) }\end{array}$ & Medium & Regulates Rab GTPases (Lindsay et al., 2002) \\
\hline & & CD2-associated protein (CD2AP) & Medium & $\begin{array}{l}\text { Regulates actin cytoskeleton (Kirsch et al., } \\
\text { 1999; Cormont et al., 2003) }\end{array}$ \\
\hline & & GRIP1 associated protein 1 (GRIPSP1) & Medium & $\begin{array}{l}\text { Interacting with endosomal SNARE syntaxin } 13 \\
\text { (Hoogenraad et al., 2010) }\end{array}$ \\
\hline & Rab8b & Otoferlin (OTOF) & Low & $\begin{array}{l}\text { Calcium sensor, regulates vesicle membrane } \\
\text { fusion in calcium-dependent manner (Roux } \\
\text { et al., 2006) }\end{array}$ \\
\hline & & $\begin{array}{l}\text { Synaptotagmin-like } 1 \\
\text { (SYTL1)/SLP1/exophilin-7 }\end{array}$ & Medium & Binds to PI3,4,5P3 (Hattula et al., 2006) \\
\hline & & $\begin{array}{l}\text { Optineurin/RAB11 family-interacting } \\
\text { protein } 2 \text { (OPTN/RAB11FIP2) }\end{array}$ & Medium & Interacts with myosin VI (Ying and Yue, 2012) \\
\hline & & $\begin{array}{l}\text { Mitogen-activated protein kinase kinase } \\
\text { kinase kinase } 2 \text { (MAP4K2) }\end{array}$ & Medium & $\begin{array}{l}\text { Serine/threonine protein kinase (Katz et al., } \\
\text { 1994; Ren et al., 1996) }\end{array}$ \\
\hline & & $\begin{array}{l}\text { MICAL (microtubule associated } \\
\text { monooxygenase, calponin, and LIM } \\
\text { domain containing)-like } 1 \text { (MICALL1) }\end{array}$ & Medium & $\begin{array}{l}\text { Linking EHD1 and Rab8 on recycling } \\
\text { endosomal membrane tubules (Sharma et al., } \\
\text { 2009) }\end{array}$ \\
\hline & & $\begin{array}{l}\text { MICAL (microtubule associated } \\
\text { monooxygenase, calponin, and LIM } \\
\text { domain containing)-like } 2 \\
\text { (MICALL2)/junctional Rab13-binding } \\
\text { protein (JRAB) }\end{array}$ & Low & $\begin{array}{l}\text { Regulates the endocytic recycling of occludins, } \\
\text { claudins and E-cadherin to the plasma } \\
\text { membrane, may regulate actin cytoskeleton } \\
\text { (Yamamura et al., 2008) }\end{array}$ \\
\hline & & $\begin{array}{l}\text { Oculocerebrorenal syndrome of Lowe } \\
\text { (OCRL) }\end{array}$ & $\begin{array}{l}\text { Mixed reports of low } \\
\text { and high expression }\end{array}$ & $\begin{array}{l}\text { Phosphatase enzyme involved in actin } \\
\text { polymerization and may function in lysosomal } \\
\text { membrane trafficking (Hagemann et al., 2012; } \\
\text { Luo et al., 2012) }\end{array}$ \\
\hline & & Myosin 5B (MYO5B) & Low & $\begin{array}{l}\text { Motor protein, travels toward the plus end of } \\
\text { actin filaments (Khandelwal et al., 2013) }\end{array}$ \\
\hline & Rab35 & $\begin{array}{l}\text { Oculocerebrorenal syndrome of Lowe } \\
\text { OCRL }\end{array}$ & $\begin{array}{l}\text { Mixed reports of low } \\
\text { and high expression }\end{array}$ & $\begin{array}{l}\text { Phosphatase enzyme involved in actin } \\
\text { polymerization and may function in lysosomal } \\
\text { membrane trafficking (Dambournet et al., 2011) }\end{array}$ \\
\hline & & Fascin actin-bundling protein 1 (FSCN1) & Medium & Actin crosslinking protein (Zhang et al., 2009) \\
\hline & & $\begin{array}{l}\text { Run and SH3 domain containing } 1 \\
\text { (RUSC1/NESCA) }\end{array}$ & Low & $\begin{array}{l}\text { RUN and SH3 domain containing protein } \\
\text { (Fukuda et al., 2011; Chaineau et al., 2013) }\end{array}$ \\
\hline & & $\begin{array}{l}\text { Microtubule associated monooxygenase, } \\
\text { Calponin and LIM domain containing } 1 \\
\text { (MICAL1) }\end{array}$ & Medium/High & $\begin{array}{l}\text { Disassemble actin filament (Chaineau et al., } \\
\text { 2013) }\end{array}$ \\
\hline & & MICAL like protein 1 (MICAL-L1) & Medium/High & Interacting with EHD1 (Rahajeng et al., 2012) \\
\hline & & $\begin{array}{l}\text { ArfGAP with coiled-coil, Ankyrin repeat } \\
\text { and PH domains } 2 \text { (ACAP2) }\end{array}$ & Medium & Arf GAP (Kobayashi and Fukuda, 2012) \\
\hline
\end{tabular}


TABLE 1 | Continued

\begin{tabular}{|c|c|c|c|c|}
\hline $\begin{array}{l}\text { Signaling } \\
\text { molecule }\end{array}$ & Rabs & Effectors & Effector expression in $\mathrm{T}$ cell & Proposed functions \\
\hline \multirow[t]{7}{*}{ Lck } & Rab11b & $\begin{array}{l}\text { Optineurin/RAB11 } \\
\text { family-interacting protein } 2 \\
\text { (OPTN/RAB11FIP2) }\end{array}$ & Medium & $\begin{array}{l}\text { Interacts with myosin VI (Wandinger-Ness and } \\
\text { Zerial, 2014) }\end{array}$ \\
\hline & & $\begin{array}{l}\text { Phosphatidylinositol 4-kinase } \\
\text { beta (PI4KB) }\end{array}$ & High & $\begin{array}{l}\text { Regulates the trafficking from Golgi to plasma } \\
\text { membrane (de Graaf et al., 2004) }\end{array}$ \\
\hline & & $\begin{array}{l}\text { TBC1 domain family membrane } \\
14 \text { (TBC1D14) }\end{array}$ & Low & $\begin{array}{l}\text { Regulates autophagosome formation (Longatti } \\
\text { et al., 2012) }\end{array}$ \\
\hline & & $\begin{array}{l}\text { WD repeat domain } \\
\text { 44/Rabphilin-11/rab11-binding } \\
\text { protein (WDR44) }\end{array}$ & High & $\begin{array}{l}\text { Plays a role in endosome recycling (Wandinger-Ness } \\
\text { and Zerial, 2014; Vetter et al., 2015) }\end{array}$ \\
\hline & & $\begin{array}{l}\text { Zinc finger FYVE } \\
\text { domain-containing } 27 \text { (ZFYVE27) }\end{array}$ & Medium & $\begin{array}{l}\text { Functions as an upstream inhibitor of Rab11 } \\
\text { (Shirane and Nakayama, 2006) }\end{array}$ \\
\hline & & $\begin{array}{l}\text { Exocyst complex component } 6 \\
(\text { EXOC6)/Sec15 }\end{array}$ & Medium & $\begin{array}{l}\text { Essential for vesicular traffic from Golgi apparatus to } \\
\text { the cell surface (Zhang et al., 2004; Wu et al., 2005) }\end{array}$ \\
\hline & & Myosin 5B (MYO5B) & Low & $\begin{array}{l}\text { Motor protein, travels toward the plus end of actin } \\
\text { filaments (Roland et al., 2011) }\end{array}$ \\
\hline \multirow[t]{9}{*}{ LAT } & Rab27a & $\begin{array}{l}\text { Synaptotagmin-like } 2 \\
\text { (SYTL2)/SLP2-a/exophilin-4 }\end{array}$ & High & $\begin{array}{l}\text { Calcium sensor, binds to PS, PI(4,5)P2 } \\
\text { (Galvez-Santisteban et al., 2012) }\end{array}$ \\
\hline & & $\begin{array}{l}\text { Synaptotagmin-like } 1 \\
\text { (SYTL1)/SLP1/exophilin-7 }\end{array}$ & Medium & $\begin{array}{l}\text { Calcium sensor, binds to PI(3,4,5)P3 (Brzezinska } \\
\text { et al., 2008) }\end{array}$ \\
\hline & & $\begin{array}{l}\text { Synaptotagmin-like } 3 \\
\text { (SYTL3)/SLP3-a/exophilin-6 }\end{array}$ & Low & $\begin{array}{l}\text { Forms Rab27a/kinesin-1/SYTL3 complex (Gibbs } \\
\text { et al., 2004; Fukuda, 2013) }\end{array}$ \\
\hline & & $\begin{array}{l}\text { Unc-13 homolog D } \\
\text { (Unc13d)/Munc13-4 }\end{array}$ & High & $\begin{array}{l}\text { Controls the priming/fusion step of LG exocytosis } \\
\text { (Feldmann et al., 2003; Brzezinska et al., 2008) }\end{array}$ \\
\hline & & Myosin 5B (MYO5B) & Low & $\begin{array}{l}\text { Travels toward the plus end of actin filaments (Gibbs } \\
\text { et al., 2004; Fukuda, 2013) }\end{array}$ \\
\hline & & $\begin{array}{l}\text { Rabphilin 3A like (without C2 } \\
\text { domain; RPH3AL) }\end{array}$ & Low & $\begin{array}{l}\text { A direct regulatory role in calcium ion-dependent } \\
\text { exocytosis (Izumi, 2007; Fukuda, 2013) }\end{array}$ \\
\hline & & Melanophilin (MLPH) & Medium & $\begin{array}{l}\text { Forms a ternary complex with Rab27a and myosin } \\
\text { Va (Strom et al., 2002) }\end{array}$ \\
\hline & & $\begin{array}{l}\text { Coronin, actin-binding protein, } \\
1 \mathrm{C}(\mathrm{CORO1C})\end{array}$ & Low & $\begin{array}{l}\text { Binds to GDP-bound form of Rab27a, regulates } \\
\text { endocytosis of secretory membrane (Kimura et al., } \\
\text { 2008) }\end{array}$ \\
\hline & Rab37 & $\begin{array}{l}\text { Regulating synaptic membrane } \\
\text { exocytosis } 1 \text { (RIMS1) }\end{array}$ & Low & $\begin{array}{l}\text { Regulates synaptic vesicle exocytosis, regulates } \\
\text { voltage-gated calcium channels, scaffolding protein } \\
\text { (Wandinger-Ness and Zerial, 2014) }\end{array}$ \\
\hline
\end{tabular}

In other reports, vSNARE VAMP2, VAMP8, tSNARE Stx7, Stx 11 Vtilb were found to be involved in LG secretion (Dressel et al., 2010; Pattu et al., 2011; Qu et al., 2011; Halimani et al., 2014; Marshall et al., 2015). For TCR exocytosis, vSNARE, VAMP2, VAMP3, VAMP7 as well as tSNARE Vti1B have been shown to play a role (Das et al., 2004; Pattu et al., 2011; Qu et al., 2011; Matti et al., 2013; Soares et al., 2013a; Finetti et al., 2015b). In Jurkat cells, tSNARE SNAP23 and Stx4 accumulated at the immunological synapse indicating that those SNAREs may also play a role in regulated exocytosis upon TCR activation (Das et al., 2004). Exocytosis of Lat vesicles in response to TCR activation relies on VAMP7 and synaptotagmin 7 (Syt7). Although vesicle fusion is the classical role of Syt7, no evidence has emerged to date that VAMP7- and Syt7-positive LAT vesicles fuse with the plasma membrane but it remains an open question whether LAT vesicles in activated T cells dock at or fuse with the plasma membrane (Williamson et al., 2011; Larghi et al.,
2013; Soares et al., 2013a). Further work is required to draw a more complete picture of how SNARE complexes regulate the secretion of LG and the exocytosis of receptors and signaling molecules. The ultimate goal is to understand how such a great diversity and redundancy in the tethering-fusion apparatus during $\mathrm{T}$ cell activation regulate the fusion of TCR, Lat, or Lck containing vesicles to specific areas of the immunological synapse.

\section{ADDITIONAL TRAFFICKING MECHANISMS FOR TCR SIGNALING MOLECULES}

In addition to the classical machinery mediating traffickingfacilitated by Rab proteins-and fusion to the plasma membrane-facilitated by SNARES-other proteins have also been demonstrated to regulate the targeting of TCR, Lck, 
and LAT to the immune synapse. Sorting nexin 17 (SNX17) and SNX27 are implicated in recycling TCR toward the immunological synapse (Rincon et al., 2011; Osborne et al., 2015). Intraflagellar transport (IFT) particles generally mediate the assembly of cilia, but in T cells, IFT20 was found to co-localize with the microtubule organizing center (MTOC), and Golgi and post-Golgi compartments. Knocking down IFT20 resulted in the TCR-CD3 complex accumulating in Rab5 endosomes and failure to be properly recycled toward the immunological synapse (Finetti et al., 2009, 2015a; Finetti and Baldari, 2013). Recently, Vivar and colleagues demonstrated that IFT20 was also required for the delivery of the intracellular pool of LAT to the immunological synapse in primary murine $\mathrm{CD} 4+\mathrm{T}$ cell (Vivar et al., 2016). The polarized recycling of TCR signaling proteins appears to be highly regulated. Indeed, Lck delivery to the immunological synapse relies on Unc119, which controls the transportation of Lck-positive endosomal compartments by regulating Rab11 activation, and orchestrating the recruitment of the actin-based motor protein, myosin 5B (Gorska et al., 2009). In addition, the membrane protein MAL, which is redistributed to the cSMAC upon $\mathrm{T}$ cell activation, contributes to target the delivery of Lck and LAT to the center of the immunological synapse (Anton et al., 2008, 2011). Microtubule plus end binding protein EB1 may contribute in directing LAT vesicles to the TCR-ZAP70 signaling complex. Indeed, in activated cells, knocking down EB1 impairs TCR clustering at the plasma membrane and the sustained activation of LAT and PLC $\gamma 1$. But more importantly, the absence of EB1 prevents the encounters between LAT vesicles and $\mathrm{CD} 3$ vesicles at the immunological synapse (Martin-Cofreces et al., 2012).

Together, these studies show that several regulators are involved in fine-tuning how and when vesicles from the recycling pathway are redirected to bring components of the TCR signaling pathway to the immunological synapse. This suggests that targeted recycling has a critical role in $\mathrm{T}$ cell activation, which probably goes beyond the mere shuttling of membrane proteins to the plasma membrane, and might contribute to the spatiotemporal regulation of TCR signaling.

\section{TRAFFICKING VS. SIGNALING -THE EXAMPLE OF LAT-POSITIVE VESICLES}

LAT is an essential adaptor protein that is recruited to phosphorylated TCR-CD3 complexes at the cell surface. The kinase ZAP70 is responsible for phosphorylating tyrosine residues in cytoplasmic tail of LAT. Due to the nine tyrosine residues, LAT acts as a scaffolding protein for downstream signaling molecules including SLP-76, PLC- $\gamma 1$, Grb2, Gads, Sos1, and so on. Recently the interactome of LAT was mapped out, which revealed 112 unique interactions in the ZAP70-LAT-SLP76 signaling axis (Malissen et al., 2014). Previous imaging and biochemistry studies identified two pools of LAT, a cytoplasmic vesicular pool, and a plasma membrane pool that forms nanoclusters. To date, the functional differences between these two pools of LAT is not clear but the notion was put forward that LAT at the plasma membrane is involved in initial TCR signaling while vesicular LAT is required for signal amplification
(Bonello et al., 2004; Purbhoo et al., 2010; Williamson et al., 2011; Balagopalan et al., 2013; Larghi et al., 2013; Soares et al., 2013a).

With respect to LAT vesicles, calcium fluxes in the context of Lck-mediated TCR signaling have emerged as one of the key factors in regulating the trafficking of these vesicles. Calcium influx initiated by the first wave of TCR signaling triggers the sub-synaptic LAT vesicle exocytosis which further propagates TCR signaling (Soares et al., 2013a). TCR activation initiates Lck spatial reorganization that conditions subsequent LAT vesicle delivery. Interfering with Lck translocation by knocking down MAL protein impairs LAT vesicle exocytosis. However it can be rescued by artificially creating calcium influx (Soares et al., 2013a). Reducing LAT exocytosis, by interfering with Lck exocytosis, or silencing calcium sensor Syt7 or vesicle SNARE VAMP7 decreased LAT phosphorylation and IL2 production in general (Williamson et al., 2011; Larghi et al., 2013; Soares et al., 2013a). Single molecule localization microscopy (SMLM) revealed that LAT and pLAT clusters number as well as cluster size decreased by blocking LAT vesicle exocytosis during TCR activation (Larghi et al., 2013). Moreover, the presence of interacting signaling nano-territories between LAT and SLP76 was also impaired by blocking LAT exocytosis (Soares et al., 2013a). Interestingly, the long, tubular-shaped LAT clusters almost disappeared when LAT exocytosis was blocked (Soares et al., 2013a). These long tubular LAT vesicles travel toward the immunological synapse during TCR activation (Bonello et al., 2004; Billadeau, 2010), supporting the idea that LAT vesicles do not fuse with the immunological synapse. Larghi et al. expressed LAT molecule that presented a HA-TEV-tag on the extracellular site. By cleaving the HA tag with TEV protease in plasma membrane LAT population before T cell activation, despite the enrichment of HA-TEV-LAT vesicles at the sub-synaptic membrane after TCR stimulation, LAT was not recognized with antibodies to HA in non-permeabilized cells, indicating that HA-TEV-LAT vesicles had not fused with the plasma membrane (Larghi et al., 2013). Since LAT vesicles appear to carry phosphorylated LAT in activated T cells (Williamson et al., 2011), it is possible that vesicular LAT is phosphorylated in trans by the TCR-ZAP70 complex in the plasma membrane. Given that LAT vesicles appear to dock at the plasma membrane for only $\sim 1$ min (Purbhoo et al., 2010; Williamson et al., 2011), many LAT molecules could be rapidly phosphorylated in that manner, leading to signal amplification and spreading throughout the cell.

\section{CONCLUSION}

Extensive research has focused on understanding the TCR signaling network and signal-regulating mechanisms during $\mathrm{T}$ cell activation due to the essential roles of $\mathrm{T}$ cells in the adaptive immune system. Surprisingly, current knowledge of the trafficking machineries involved in the intracellular movement of TCR and signaling molecules remains very limited. In this review, we attempted to summarize the known trafficking machinery involved in the exocytosis of TCR, downstream signaling molecules and effectors during TCR activation. By putting this information into context, we tried to draw a more complete 
picture of trafficking networks involved in the regulation of TCR signaling.

It emerges that key signaling molecules involved in early TCR signaling reside in distinct vesicle subpopulations that contain non-overlapping SNARE molecules (Das et al., 2004; Pattu et al., 2012; Larghi et al., 2013; Matti et al., 2013; Finetti et al., 2015b). Despite their differences, it seems that fusion with the plasma membrane might not be the final destination of some populations of vesicles, raising the question of how trafficking per se can contribute to regulate $\mathrm{T}$ cell signaling. Rather than distributing signaling molecules across the cell, and regulating signaling by changing the local concentration of available signaling molecules, vesicles themselves may be signaling entities. This is illustrated in the emerging concept of LAT vesicles that do not appear to fuse with the plasma membrane but are nevertheless phosphorylated upon TCR stimulation (Williamson et al., 2011; Larghi et al., 2013). Such vesicles resemble signaling endosomes (Benzing et al., 2013) but contain the trafficking machinery for exocytosis (Larghi et al., 2013; Soares et al., 2013a). Thus, LAT vesicles blur the lines between exocytosis, endocytosis, and signaling. Quantitative imaging may reveal whether LAT vesicles indeed amplify the initial TCR signals in the coming years. This would constitute a new perspective, as the trafficking machinery is not solely used to deliver molecules to and from the plasma membrane but to directly facilitate the signaling process in a highly controlled manner.

It is tempting to speculate that the different trafficking machinery is required to segregate Lck and LAT into different

\section{REFERENCES}

Angus, K. L., and Griffiths, G. M. (2013). Cell polarisation and the immunological synapse. Curr. Opin. Cell Biol. 25, 85-91. doi: 10.1016/j.ceb.2012.08.013

Anton, O., Batista, A., Millan, J., Andres-Delgado, L., Puertollano, R., Correas, I., et al. (2008). An essential role for the MAL protein in targeting Lck to the plasma membrane of human T lymphocytes. J. Exp. Med. 205, 3201-3213. doi: 10.1084/jem.20080552

Anton, O. M., Andres-Delgado, L., Reglero-Real, N., Batista, A., and Alonso, M. A. (2011). MAL protein controls protein sorting at the supramolecular activation cluster of human T lymphocytes. J. Immunol. 186, 6345-6356. doi: 10.4049/jimmunol.1003771

Balagopalan, L., Barr, V. A., Kortum, R. L., Park, A. K., and Samelson, L. E. (2013). Cutting edge: cell surface linker for activation of $\mathrm{T}$ cells is recruited to microclusters and is active in signaling. J. Immunol. 190, 3849-3853. doi: 10.4049/jimmunol.1202760

Balagopalan, L., Barr, V. A., and Samelson, L. E. (2009). Endocytic events in TCR signaling: focus on adapters in microclusters. Immunol. Rev. 232, 84-98. doi: 10.1111/j.1600-065X.2009.00840.x

Balagopalan, L., Barr, V. A., Sommers, C. L., Barda-Saad, M., Goyal, A., Isakowitz, M. S., et al. (2007). c-Cbl-mediated regulation of LAT-nucleated signaling complexes. Mol. Cell. Biol. 27, 8622-8636. doi: 10.1128/MCB.00467-07

Barr, V. A., Balagopalan, L., Barda-Saad, M., Polishchuk, R., Boukari, H., Bunnell, S. C., et al. (2006). T-cell antigen receptor-induced signaling complexes: internalization via a cholesterol-dependent endocytic pathway. Traffic 7, 1143-1162. doi: 10.1111/j.1600-0854.2006.00464.x

Benzing, C., Rossy, J., and Gaus, K. (2013). Do signalling endosomes play a role in T cell activation? FEBS J. 280, 5164-5176. doi: 10.1111/febs.12427

Billadeau, D. D. (2010). T cell activation at the immunological synapse: vesicles emerge for LATer signaling. Sci. Signal. 3:pe16. doi: 10.1126/scisignal.3121pe16 vesicles from those that contain TCR and the CD3 complex. Such segregation may be necessary to achieve the distinct spatial organization of the immunological synapse. Emerging imaging techniques such as the lattice light-sheet microscope (Chen et al., 2014) may soon reveal how vesicle trafficking is functionally linked to synapse organization. Segregation into different membrane compartments could both prevent signaling in resting $\mathrm{T}$ cells and facilitate sustained signaling in activated $\mathrm{T}$ cells. Already the actin cytoskeleton at the immunological synapse has been identified as a gatekeeper for the secretion of LG (Ritter et al., 2015) and new rapid, super-resolution imaging will undoubtedly bring further insights into the interconnectedness between the structural organization of the synapse, signaling activities, compartmentalization of signaling components, and vesicle movement.

\section{AUTHOR CONTRIBUTIONS}

JL and QD wrote the manuscript, KG, JR, and SP provided critical reviewing and editing.

\section{FUNDING}

We acknowledge funding from the Australia Research Council (CE14010011 to KG and DE140101626 to JR) and National Health and Medical Research Council of Australia (APP1037320 and APP1059278 to KG and APP1102730 to JR).
Bonello, G., Blanchard, N., Montoya, M. C., Aguado, E., Langlet, C., He, H. T., et al. (2004). Dynamic recruitment of the adaptor protein LAT: LAT exists in two distinct intracellular pools and controls its own recruitment. J. Cell Sci. 117, 1009-1016. doi: 10.1242/jcs.00968

Brzezinska, A. A., Johnson, J. L., Munafo, D. B., Crozat, K., Beutler, B., Kiosses, W. B., et al. (2008). The Rab27a effectors JFC1/Slp1 and Munc13-4 regulate exocytosis of neutrophil granules. Traffic 9, 2151-2164. doi: 10.1111/j.16000854.2008.00838.x

Chaineau, M., Ioannou, M. S., and McPherson, P. S. (2013). Rab35: GEFs, GAPs and effectors. Traffic 14, 1109-1117. doi: 10.1111/tra.12096

Chen, B. C., Legant, W. R., Wang, K., Shao, L., Milkie, D. E., Davidson, M. W., et al. (2014). Lattice light-sheet microscopy: imaging molecules to embryos at high spatiotemporal resolution. Science 346:1257998. doi: 10.1126/science.1257998

Choudhuri, K., Llodra, J., Roth, E. W., Tsai, J., Gordo, S., Wucherpfennig, K. W., et al. (2014). Polarized release of T-cell-receptor-enriched microvesicles at the immunological synapse. Nature 507, 118-123. doi: 10.1038/nature 12951

Coombs, D., Kalergis, A. M., Nathenson, S. G., Wofsy, C., and Goldstein, B. (2002). Activated TCRs remain marked for internalization after dissociation from pMHC. Nat. Immunol. 3, 926-931. doi: 10.1038/ni838

Cormont, M., Mari, M., Galmiche, A., Hofman, P., and Le Marchand-Brustel, Y. (2001). A FYVE-finger-containing protein, Rabip4, is a Rab4 effector involved in early endosomal traffic. Proc. Natl. Acad. Sci. U.S.A. 98, 1637-1642. doi: 10.1073/pnas.98.4.1637

Cormont, M., Meton, I., Mari, M., Monzo, P., Keslair, F., Gaskin, C., et al. (2003). $\mathrm{CD} 2 \mathrm{AP} / \mathrm{CMS}$ regulates endosome morphology and traffic to the degradative pathway through its interaction with Rab4 and c-Cbl. Traffic 4, 97-112. doi: 10.1034/j.1600-0854.2003.40205.x

Dambournet, D., Machicoane, M., Chesneau, L., Sachse, M., Rocancourt, M., El Marjou, A., et al. (2011). Rab35 GTPase and OCRL phosphatase remodel 
lipids and F-actin for successful cytokinesis. Nat. Cell Biol. 13, 981-988. doi: $10.1038 /$ ncb2279

Das, V., Nal, B., Dujeancourt, A., Thoulouze, M. I., Galli, T., Roux, P., et al. (2004). Activation-induced polarized recycling targets $\mathrm{T}$ cell antigen receptors to the immunological synapse; involvement of SNARE complexes. Immunity 20, 577-588. doi: 10.1016/S1074-7613(04)00106-2

de Graaf, P., Zwart, W. T., van Dijken, R. A., Deneka, M., Schulz, T. K., Geijsen, N., et al. (2004). Phosphatidylinositol 4-kinasebeta is critical for functional association of rab11 with the Golgi complex. Mol. Biol. Cell 15, 2038-2047. doi: 10.1091/mbc.E03-12-0862

Dressel, R., Elsner, L., Novota, P., Kanwar, N., and Fischer von Mollard, G. (2010). The exocytosis of lytic granules is impaired in Vtilb- or Vamp8-deficient CTL leading to a reduced cytotoxic activity following antigen-specific activation. J. Immunol. 185, 1005-1014. doi: 10.4049/jimmunol.1000770

Dustin, M. L., and Cooper, J. A. (2000). The immunological synapse and the actin cytoskeleton: molecular hardware for T cell signaling. Nat. Immunol. 1, 23-29. doi: $10.1038 / 76877$

Ehrlich, L. I., Ebert, P. J., Krummel, M. F., Weiss, A., and Davis, M. M. (2002). Dynamics of p56lck translocation to the T cell immunological synapse following agonist and antagonist stimulation. Immunity 17, 809-822. doi: 10.1016/S1074-7613(02)00481-8

Feldmann, J., Callebaut, I., Raposo, G., Certain, S., Bacq, D., Dumont, C., et al. (2003). Munc13-4 is essential for cytolytic granules fusion and is mutated in a form of familial hemophagocytic lymphohistiocytosis (FHL3). Cell 115, 461-473. doi: 10.1016/S0092-8674(03)00855-9

Finetti, F., and Baldari, C. T. (2013). Compartmentalization of signaling by vesicular trafficking: a shared building design for the immune synapse and the primary cilium. Immunol. Rev. 251, 97-112. doi: 10.1111/imr.12018

Finetti, F., Onnis, A., and Baldari, C. T. (2015a). Regulation of vesicular traffic at the $\mathrm{T}$ cell immune synapse: lessons from the primary cilium. Traffic 16, 241-249. doi: 10.1111/tra.12241

Finetti, F., Paccani, S. R., Riparbelli, M. G., Giacomello, E., Perinetti, G., Pazour, G. J., et al. (2009). Intraflagellar transport is required for polarized recycling of the TCR/CD3 complex to the immune synapse. Nat. Cell Biol. 11, 1332-1339. doi: 10.1038/ncb1977

Finetti, F., Patrussi, L., Galgano, D., Cassioli, C., Perinetti, G., Pazour, G. J., et al. (2015b). The small GTPase Rab8 interacts with VAMP-3 to regulate the delivery of recycling T-cell receptors to the immune synapse. J. Cell Sci. 128, 2541-2552. doi: $10.1242 /$ jcs. 171652

Fischer, A., Latour, S., and de Saint Basile, G. (2007). Genetic defects affecting lymphocyte cytotoxicity. Curr. Opin. Immunol. 19, 348-353. doi: 10.1016/j.coi.2007.04.006

Fouraux, M. A., Deneka, M., Ivan, V., van der Heijden, A., Raymackers, J., van Suylekom, D., et al. (2004). Rabip4' is an effector of rab5 and rab4 and regulates transport through early endosomes. Mol. Biol. Cell 15, 611-624. doi: 10.1091/mbc.E03-05-0343

Freiberg, B. A., Kupfer, H., Maslanik, W., Delli, J., Kappler, J., Zaller, D. M., et al. (2002). Staging and resetting T cell activation in SMACs. Nat. Immunol. 3, 911-917. doi: 10.1038/ni836

Fukuda, M. (2008). Regulation of secretory vesicle traffic by Rab small GTPases. Cell. Mol. Life Sci. 65, 2801-2813. doi: 10.1007/s00018-008-8351-4

Fukuda, M. (2013). Rab27 effectors, pleiotropic regulators in secretory pathways. Traffic 14, 949-963. doi: 10.1111/tra.12083

Fukuda, M., Kobayashi, H., Ishibashi, K., and Ohbayashi, N. (2011). Genome-wide investigation of the Rab binding activity of RUN domains: development of a novel tool that specifically traps GTP-Rab35. Cell Struct. Funct. 36, 155-170. doi: $10.1247 /$ csf. 11001

Galvez-Santisteban, M., Rodriguez-Fraticelli, A. E., Bryant, D. M., Vergarajauregui, S., Yasuda, T., Banon-Rodriguez, I., et al. (2012). Synaptotagmin-like proteins control the formation of a single apical membrane domain in epithelial cells. Nat. Cell Biol. 14, 838-849. doi: 10.1038/ncb2541

Gandini, M. A., Sandoval, A., Gonzalez-Ramirez, R., Mori, Y., de Waard, M., and Felix, R. (2011). Functional coupling of Rab3-interacting molecule 1 (RIM1) and L-type Ca2+ channels in insulin release. J. Biol. Chem. 286, 15757-15765. doi: $10.1074 /$ jbc.M110.187757

Geisler, C. (2004). TCR trafficking in resting and stimulated T cells. Crit. Rev. Immunol. 24, 67-86. doi: 10.1615/CritRevImmunol.v24.i1.30
Gibbs, D., Azarian, S. M., Lillo, C., Kitamoto, J., Klomp, A. E., Steel, K. P., et al. (2004). Role of myosin VIIa and Rab27a in the motility and localization of RPE melanosomes. J. Cell Sci. 117, 6473-6483. doi: 10.1242/jcs.01580

Gorska, M. M., Liang, Q., Karim, Z., and Alam, R. (2009). Uncoordinated 119 protein controls trafficking of Lck via the Rab11 endosome and is critical for immunological synapse formation. J. Immunol. 183, 1675-1684. doi: 10.4049/jimmunol.0900792

Grakoui, A., Bromley, S. K., Sumen, C., Davis, M. M., Shaw, A. S., Allen, P. M., et al. (1999). The immunological synapse: a molecular machine controlling T cell activation. Science 285, 221-227. doi: 10.1126/science.285. 5425.221

Grosshans, B. L., Ortiz, D., and Novick, P. (2006). Rabs and their effectors: achieving specificity in membrane traffic. Proc. Natl. Acad. Sci. U.S.A. 103, 11821-11827. doi: 10.1073/pnas.0601617103

Hackmann, Y., Graham, S. C., Ehl, S., Honing, S., Lehmberg, K., Arico, M., et al. (2013). Syntaxin binding mechanism and disease-causing mutations in Munc18-2. Proc. Natl. Acad. Sci. U.S.A. 110, E4482-E4491. doi: 10.1073/pnas.1313474110

Haddad, E. K., Wu, X., Hammer, J. A. III, and Henkart, P. A. (2001). Defective granule exocytosis in Rab27a-deficient lymphocytes from Ashen mice. J. Cell Biol. 152, 835-842. doi: 10.1083/jcb.152.4.835

Hagemann, N., Hou, X., Goody, R. S., Itzen, A., and Erdmann, K. S. (2012). Crystal structure of the Rab binding domain of OCRL1 in complex with Rab8 and functional implications of the OCRL1/Rab8 module for Lowe syndrome. Small GTPases 3, 107-110. doi: 10.4161/sgtp.19380

Halimani, M., Pattu, V., Marshall, M. R., Chang, H. F., Matti, U., Jung, M., et al. (2014). Syntaxin11 serves as a t-SNARE for the fusion of lytic granules in human cytotoxic T lymphocytes. Eur. J. Immunol. 44, 573-584. doi: 10.1002/eji.201344011

Hattula, K., Furuhjelm, J., Tikkanen, J., Tanhuanpaa, K., Laakkonen, P., and Peranen, J. (2006). Characterization of the Rab8-specific membrane traffic route linked to protrusion formation. J. Cell Sci. 119, 4866-4877. doi: $10.1242 /$ jcs. 03275

Holt, O., Kanno, E., Bossi, G., Booth, S., Daniele, T., Santoro, A., et al. (2008). Slp1 and Slp2-a localize to the plasma membrane of CTL and contribute to secretion from the immunological synapse. Traffic 9, 446-457. doi: 10.1111/j.16000854.2008.00714.x

Hong, W. (2005). Cytotoxic T lymphocyte exocytosis: bring on the SNAREs! Trends Cell Biol. 15, 644-650. doi: 10.1016/j.tcb.2005.10.003

Hoogenraad, C. C., Popa, I., Futai, K., Martinez-Sanchez, E., Wulf, P. S., van Vlijmen, T., et al. (2010). Neuron specific Rab4 effector GRASP-1 coordinates membrane specialization and maturation of recycling endosomes. PLoS Biol. 8:e1000283. doi: 10.1371/annotation/b17dfb99-8809-4c5a-86c2-c2a0f7ca7f5e

Izumi, T. (2007). Physiological roles of Rab27 effectors in regulated exocytosis. Endocr. J. 54, 649-657. doi: 10.1507/endocrj.KR-78

Jahn, R., and Scheller, R. H. (2006). SNAREs-engines for membrane fusion. Nat. Rev. Mol. Cell Biol. 7, 631-643. doi: 10.1038/nrm2002

Jenkins, M. R., and Griffiths, G. M. (2010). The synapse and cytolytic machinery of cytotoxic T cells. Curr. Opin. Immunol. 22, 308-313. doi: 10.1016/j.coi.2010. 02.008

Katz, P., Whalen, G., and Kehrl, J. H. (1994). Differential expression of a novel protein kinase in human B lymphocytes. Preferential localization in the germinal center. J. Biol. Chem. 269, 16802-16809.

Khandelwal, P., Prakasam, H. S., Clayton, D. R., Ruiz, W. G., Gallo, L. I., van Roekel, D., et al. (2013). A Rab1la-Rab8a-Myo5B network promotes stretchregulated exocytosis in bladder umbrella cells. Mol. Biol. Cell 24, 1007-1019. doi: 10.1091/mbc.E12-08-0568

Kimura, T., Kaneko, Y., Yamada, S., Ishihara, H., Senda, T., Iwamatsu, A., et al. (2008). The GDP-dependent Rab27a effector coronin 3 controls endocytosis of secretory membrane in insulin-secreting cell lines. J. Cell Sci. 121, 3092-3098. doi: $10.1242 /$ jcs. 030544

Kirsch, K. H., Georgescu, M. M., Ishimaru, S., and Hanafusa, H. (1999). CMS: an adapter molecule involved in cytoskeletal rearrangements. Proc. Natl. Acad. Sci. U.S.A. 96, 6211-6216. doi: 10.1073/pnas.96.11.6211

Kobayashi, H., and Fukuda, M. (2012). Rab35 regulates Arf6 activity through centaurin-beta2 (ACAP2) during neurite outgrowth. J. Cell Sci. 125, 2235-2243. doi: $10.1242 /$ jcs.098657 
Krzewski, K., and Cullinane, A. R. (2013). Evidence for defective Rab GTPasedependent cargo traffic in immune disorders. Exp. Cell Res. 319, 2360-2367. doi: 10.1016/j.yexcr.2013.06.012

Kurowska, M., Goudin, N., Nehme, N. T., Court, M., Garin, J., Fischer, A., et al. (2012). Terminal transport of lytic granules to the immune synapse is mediated by the kinesin-1/Slp3/Rab27a complex. Blood 119, 3879-3889. doi: 10.1182/blood-2011-09-382556

Larghi, P., Williamson, D. J., Carpier, J. M., Dogniaux, S., Chemin, K., Bohineust, A., et al. (2013). VAMP7 controls T cell activation by regulating the recruitment and phosphorylation of vesicular Lat at TCR-activation sites. Nat. Immunol. 14, 723-731. doi: $10.1038 /$ ni.2609

Lee, K. H., Dinner, A. R., Tu, C., Campi, G., Raychaudhuri, S., Varma, R., et al. (2003). The immunological synapse balances $T$ cell receptor signaling and degradation. Science 302, 1218-1222. doi: 10.1126/science.1086507

Li, C., Takei, K., Geppert, M., Daniell, L., Stenius, K., Chapman, E. R., et al. (1994). Synaptic targeting of rabphilin-3A, a synaptic vesicle $\mathrm{Ca}^{2+} /$ phospholipid-binding protein, depends on rab3A/3C. Neuron 13, 885-898. doi: 10.1016/0896-6273(94)90254-2

Lindsay, A. J., Hendrick, A. G., Cantalupo, G., Senic-Matuglia, F., Goud, B., Bucci, C., et al. (2002). Rab coupling protein (RCP), a novel Rab4 and Rab11 effector protein. J. Biol. Chem. 277, 12190-12199. doi: 10.1074/jbc.M108665200

Liu, H., Rhodes, M., Wiest, D. L., and Vignali, D. A. (2000). On the dynamics of TCR:CD 3 complex cell surface expression and downmodulation. Immunity 13 , 665-675. doi: 10.1016/S1074-7613(00)00066-2

Longatti, A., Lamb, C. A., Razi, M., Yoshimura, S., Barr, F. A., and Tooze, S. A. (2012). TBC1D14 regulates autophagosome formation via Rab11and ULK1-positive recycling endosomes. J. Cell Biol. 197, 659-675. doi: $10.1083 /$ jcb. 201111079

Luo, N., West, C. C., Murga-Zamalloa, C. A., Sun, L., Anderson, R. M., Wells, C. D., et al. (2012). OCRL localizes to the primary cilium: a new role for cilia in Lowe syndrome. Hum. Mol. Genet. 21, 3333-3344. doi: 10.1093/hmg/dds163

Luton, F., Legendre, V., Gorvel, J. P., Schmitt-Verhulst, A. M., and Boyer, C. (1997). Tyrosine and serine protein kinase activities associated with ligand-induced internalized TCR/CD3 complexes. J. Immunol. 158, 3140-3147.

Malissen, B., Gregoire, C., Malissen, M., and Roncagalli, R. (2014). Integrative biology of T cell activation. Nat. Immunol. 15, 790-797. doi: 10.1038/ni.2959

Marshall, M. R., Pattu, V., Halimani, M., Maier-Peuschel, M., Muller, M. L., Becherer, U., et al. (2015). VAMP8-dependent fusion of recycling endosomes with the plasma membrane facilitates T lymphocyte cytotoxicity. J. Cell Biol. 210, 135-151. doi: 10.1083/jcb.201411093

Martin-Cofreces, N. B., Baixauli, F., Lopez, M. J., Gil, D., Monjas, A., Alarcon, B., et al. (2012). End-binding protein 1 controls signal propagation from the $\mathrm{T}$ cell receptor. $E M B O$ J. 31, 4140-4152. doi: 10.1038/emboj.2012.242

Martin-Cofreces, N. B., Baixauli, F., and Sanchez-Madrid, F. (2014). Immune synapse: conductor of orchestrated organelle movement. Trends Cell Biol. 24, 61-72. doi: 10.1016/j.tcb.2013.09.005

Martinez-Martin, N., Risueno, R. M., Morreale, A., Zaldivar, I., Fernandez-Arenas, E., Herranz, F., et al. (2009). Cooperativity between T cell receptor complexes revealed by conformational mutants of CD3epsilon. Sci. Signal. 2:ra43. doi: 10.1126/scisignal.2000402

Matti, U., Pattu, V., Halimani, M., Schirra, C., Krause, E., Liu, Y., et al. (2013). Synaptobrevin2 is the v-SNARE required for cytotoxic T-lymphocyte lytic granule fusion. Nat. Commun. 4:1439. doi: 10.1038/ncomms 2467

Menager, M. M., Menasche, G., Romao, M., Knapnougel, P., Ho, C. H., Garfa, M., et al. (2007). Secretory cytotoxic granule maturation and exocytosis require the effector protein hMunc13-4. Nat. Immunol. 8, 257-267. doi: 10.1038/ni1431

Menasche, G., Menager, M. M., Lefebvre, J. M., Deutsch, E., Athman, R., Lambert, N., et al. (2008). A newly identified isoform of Slp2a associates with Rab27a in cytotoxic T cells and participates to cytotoxic granule secretion. Blood 112, 5052-5062. doi: 10.1182/blood-2008-02-141069

Menasche, G., Pastural, E., Feldmann, J., Certain, S., Ersoy, F., Dupuis, S., et al. (2000). Mutations in RAB27A cause Griscelli syndrome associated with haemophagocytic syndrome. Nat. Genet. 25, 173-176. doi: 10.1038/76024

Millar, A. L., Pavios, N. J., Xu, J., and Zheng, M. H. (2002). Rab3D: a regulator of exocytosis in non-neuronal cells. Histol. Histopathol. 17, 929-936.

Monjas, A., Alcover, A., and Alarcon, B. (2004). Engaged and bystander T cell receptors are down-modulated by different endocytotic pathways. J. Biol. Chem. 279, 55376-55384. doi: 10.1074/jbc.M409342200
Monks, C. R., Freiberg, B. A., Kupfer, H., Sciaky, N., and Kupfer, A. (1998). Threedimensional segregation of supramolecular activation clusters in T cells. Nature 395, 82-86. doi: 10.1038/25764

Naramura, M., Jang, I. K., Kole, H., Huang, F., Haines, D., and Gu, H. (2002). c$\mathrm{Cbl}$ and $\mathrm{Cbl}-\mathrm{b}$ regulate $\mathrm{T}$ cell responsiveness by promoting ligand-induced TCR down-modulation. Nat. Immunol. 3, 1192-1199. doi: 10.1038/ni855

Nika, K., Soldani, C., Salek, M., Paster, W., Gray, A., Etzensperger, R., et al. (2010). Constitutively active Lck kinase in T cells drives antigen receptor signal transduction. Immunity 32, 766-777. doi: 10.1016/j.immuni.2010. 05.011

Osborne, D. G., Piotrowski, J. T., Dick, C. J., Zhang, J. S., and Billadeau, D. D. (2015). SNX17 affects T cell activation by regulating TCR and integrin recycling. J. Immunol. 194, 4555-4566. doi: 10.4049/jimmunol.1402734

Patino-Lopez, G., Dong, X., Ben-Aissa, K., Bernot, K. M., Itoh, T., Fukuda, M., et al. (2008). Rab35 and its GAP EPI64C in T cells regulate receptor recycling and immunological synapse formation. J. Biol. Chem. 283, 18323-18330. doi: 10.1074/jbc.M800056200

Pattu, V., Qu, B., Marshall, M., Becherer, U., Junker, C., Matti, U., et al. (2011). Syntaxin7 is required for lytic granule release from cytotoxic T lymphocytes. Traffic 12, 890-901. doi: 10.1111/j.1600-0854.2011.01193.x

Pattu, V., Qu, B., Schwarz, E. C., Strauss, B., Weins, L., Bhat, S. S., et al. (2012). SNARE protein expression and localization in human cytotoxic T lymphocytes. Eur. J. Immunol. 42, 470-475. doi: 10.1002/eji.201141915

Purbhoo, M. A., Liu, H., Oddos, S., Owen, D. M., Neil, M. A., Pageon, S. V., et al. (2010). Dynamics of subsynaptic vesicles and surface microclusters at the immunological synapse. Sci. Signal. 3:ra36. doi: 10.1126/scisignal.2000645

Qu, B., Pattu, V., Junker, C., Schwarz, E. C., Bhat, S. S., Kummerow, C., et al. (2011). Docking of lytic granules at the immunological synapse in human CTL requires Vtilb-dependent pairing with CD3 endosomes. J. Immunol. 186, 6894-6904. doi: 10.4049/jimmunol.1003471

Rahajeng, J., Giridharan, S. S., Cai, B., Naslavsky, N., and Caplan, S. (2012). MICAL-L1 is a tubular endosomal membrane hub that connects Rab35 and Arf6 with Rab8a. Traffic 13, 82-93. doi: 10.1111/j.1600-0854.2011.01294.x

Ren, M., Zeng, J., De Lemos-Chiarandini, C., Rosenfeld, M., Adesnik, M., and Sabatini, D. D. (1996). In its active form, the GTP-binding protein rab8 interacts with a stress-activated protein kinase. Proc. Natl. Acad. Sci. U.S.A. 93, 5151-5155. doi: 10.1073/pnas.93.10.5151

Rincon, E., Saez de Guinoa, J., Gharbi, S. I., Sorzano, C. O., Carrasco, Y. R., and Merida, I. (2011). Translocation dynamics of sorting nexin 27 in activated T cells. J. Cell Sci. 124, 776-788. doi: 10.1242/jcs.072447

Ritter, A. T., Asano, Y., Stinchcombe, J. C., Dieckmann, N. M., Chen, B. C., Gawden-Bone, C., et al. (2015). Actin depletion initiates events leading to granule secretion at the immunological synapse. Immunity 42, 864-876. doi: 10.1016/j.immuni.2015.04.013

Roland, J. T., Bryant, D. M., Datta, A., Itzen, A., Mostov, K. E., and Goldenring, J. R. (2011). Rab GTPase-Myo5B complexes control membrane recycling and epithelial polarization. Proc. Natl. Acad. Sci. U.S.A. 108, 2789-2794. doi: 10.1073/pnas.1010754108

Rossy, J., Owen, D. M., Williamson, D. J., Yang, Z., and Gaus, K. (2013). Conformational states of the kinase Lck regulate clustering in early $\mathrm{T}$ cell signaling. Nat. Immunol. 14, 82-89. doi: 10.1038/ni.2488

Roux, I., Safieddine, S., Nouvian, R., Grati, M., Simmler, M. C., Bahloul, A., et al. (2006). Otoferlin, defective in a human deafness form, is essential for exocytosis at the auditory ribbon synapse. Cell 127, 277-289. doi: 10.1016/j.cell.2006.08.040

Sharma, M., Giridharan, S. S., Rahajeng, J., Naslavsky, N., and Caplan, S. (2009). MICAL-L1 links EHD1 to tubular recycling endosomes and regulates receptor recycling. Mol. Biol. Cell 20, 5181-5194. doi: 10.1091/mbc.E09-06-0535

Shirane, M., and Nakayama, K. I. (2006). Protrudin induces neurite formation by directional membrane trafficking. Science 314, 818-821. doi: 10.1126/science. 1134027

Soares, H., Henriques, R., Sachse, M., Ventimiglia, L., Alonso, M. A., Zimmer, C., et al. (2013a). Regulated vesicle fusion generates signaling nanoterritories that control T cell activation at the immunological synapse. J. Exp. Med. 210, 2415-2433. doi: 10.1084/jem.20130150

Soares, H., Lasserre, R., and Alcover, A. (2013b). Orchestrating cytoskeleton and intracellular vesicle traffic to build functional immunological synapses. Immunol. Rev. 256, 118-132. doi: 10.1111/imr.12110 
Spessott, W. A., Sanmillan, M. L., McCormick, M. E., Patel, N., Villanueva, J., Zhang, K., et al. (2015). Hemophagocytic lymphohistiocytosis caused by dominant-negative mutations in STXBP2 that inhibit SNARE-mediated membrane fusion. Blood 125, 1566-1577. doi: 10.1182/blood-2014-11-610816

Stirnweiss, A., Hartig, R., Gieseler, S., Lindquist, J. A., Reichardt, P., Philipsen, L., et al. (2013). T cell activation results in conformational changes in the Src family kinase Lck to induce its activation. Sci. Signal. 6:ra13. doi: 10.1126/scisignal.2003607

Strom, M., Hume, A. N., Tarafder, A. K., Barkagianni, E., and Seabra, M. C. (2002). A family of Rab27-binding proteins. Melanophilin links Rab27a and myosin Va function in melanosome transport. J. Biol. Chem. 277, 25423-25430. doi: 10.1074/jbc.M202574200

Swamy, M., Beck-Garcia, K., Beck-Garcia, E., Hartl, F. A., Morath, A., Yousefi, O. S., et al. (2016). A cholesterol-based allostery model of T cell receptor phosphorylation. Immunity 44, 1091-1101. doi: 10.1016/j.immuni.2016.04.011

Thoulouze, M. I., Sol-Foulon, N., Blanchet, F., Dautry-Varsat, A., Schwartz, O., and Alcover, A. (2006). Human immunodeficiency virus type-1 infection impairs the formation of the immunological synapse. Immunity 24, 547-561. doi: 10.1016/j.immuni.2006.02.016

Vetter, M., Wang, J., Lorentzen, E., and Deretic, D. (2015). Novel topography of the Rab11-effector interaction network within a ciliary membrane targeting complex. Small GTPases 6, 165-173. doi: 10.1080/21541248.2015.1091539

Vitale, G., Rybin, V., Christoforidis, S., Thornqvist, P., McCaffrey, M., Stenmark, H., et al. (1998). Distinct Rab-binding domains mediate the interaction of Rabaptin-5 with GTP-bound Rab4 and Rab5. ЕMBO J. 17, 1941-1951. doi: 10.1093/emboj/17.7.1941

Vivar, O. I., Masi, G., Carpier, J. M., Magalhaes, J. G., Galgano, D., Pazour, G. J., et al. (2016). IFT20 controls LAT recruitment to the immune synapse and T-cell activation in vivo. Proc. Natl. Acad. Sci. U.S.A. 113, 386-391. doi: $10.1073 /$ pnas. 1513601113

von Essen, M., Bonefeld, C. M., Siersma, V., Rasmussen, A. B., Lauritsen, J. P., Nielsen, B. L., et al. (2004). Constitutive and ligand-induced TCR degradation. J. Immunol. 173, 384-393. doi: 10.4049/jimmunol.173.1.384

Wandinger-Ness, A., and Zerial, M. (2014). Rab proteins and the compartmentalization of the endosomal system. Cold Spring Harb. Perspect. Biol. 6:a022616. doi: 10.1101/cshperspect.a022616
Williamson, D. J., Owen, D. M., Rossy, J., Magenau, A., Wehrmann, M., Gooding, J. J., et al. (2011). Pre-existing clusters of the adaptor Lat do not participate in early $\mathrm{T}$ cell signaling events. Nat. Immunol. 12, 655-662. doi: 10.1038/ ni.2049

Wu, S., Mehta, S. Q., Pichaud, F., Bellen, H. J., and Quiocho, F. A. (2005). Sec15 interacts with Rab11 via a novel domain and affects Rab11 localization in vivo. Nat. Struct. Mol. Biol. 12, 879-885. doi: 10.1038/ nsmb987

Yamamura, R., Nishimura, N., Nakatsuji, H., Arase, S., and Sasaki, T. (2008). The interaction of JRAB/MICAL-L2 with Rab8 and Rab13 coordinates the assembly of tight junctions and adherens junctions. Mol. Biol. Cell 19, 971-983. doi: 10.1091/mbc.E07-06-0551

Ying, H., and Yue, B. Y. (2012). Cellular and molecular biology of optineurin. Int. Rev. Cell Mol. Biol. 294, 223-258. doi: 10.1016/B978-0-12-394305-7. 00005-7

Yudushkin, I. A., and Vale, R. D. (2010). Imaging T-cell receptor activation reveals accumulation of tyrosine-phosphorylated CD3zeta in the endosomal compartment. Proc. Natl. Acad. Sci. U.S.A. 107, 22128-22133. doi: 10.1073/pnas.1016388108

Zhang, J., Fonovic, M., Suyama, K., Bogyo, M., and Scott, M. P. (2009). Rab35 controls actin bundling by recruiting fascin as an effector protein. Science 325 , 1250-1254. doi: 10.1126/science.1174921

Zhang, X. M., Ellis, S., Sriratana, A., Mitchell, C. A., and Rowe, T. (2004). Sec15 is an effector for the Rab11 GTPase in mammalian cells. J. Biol. Chem. 279, 43027-43034. doi: 10.1074/jbc.M402264200

Conflict of Interest Statement: The authors declare that the research was conducted in the absence of any commercial or financial relationships that could be construed as a potential conflict of interest.

Copyright (c) 2016 Lou, Rossy, Deng, Pageon and Gaus. This is an open-access article distributed under the terms of the Creative Commons Attribution License (CC BY). The use, distribution or reproduction in other forums is permitted, provided the original author(s) or licensor are credited and that the original publication in this journal is cited, in accordance with accepted academic practice. No use, distribution or reproduction is permitted which does not comply with these terms. 